\title{
CONSIDERATION OF FOREST ECOSYSTEM SERVICES IN ENVIRONMENTAL MANAGEMENT ACCOUNTING
}

\author{
Miroslav Hájek, Pavla Vrabcová \\ Czech University of Life Sciences Prague \\ Czech Republic \\ (Received March 20I9)
}

\begin{abstract}
The environmental management accounting aims at capturing economic and environmental benefits and it should include externalities too. The aim of the paper is to propose a methodological approach for how to include non-market forest ecosystem services in the environmental management accounting so that the information could be used in economic analyzes. For this purpose, it is necessary to identify information relevant to related costs, sales revenues and the value of non-production ecosystem services. It is possible to perform the financial analysis needed for decision making in forest management. In the University Forest Establishment, the rated value of non-market ecosystem services was 3.2 million EUR, and this value was estimated to be twice as much as the value of market ecosystem services. In the Forest Plant Židlochovice, the value of non-market ecosystem services was 0.4 million EUR. Profitability increased from 1.346 to 4.093 and from 1.181 to 3.492 .
\end{abstract}

KEYWORDS: Ecosystem services, externalities, forestry enterprises, forest services, management accounting, valuation.

\section{INTRODUCTION}

In connection with the strategic international forestry documents, it is clear that increasing attention is being paid to forest ecosystem services and their development in response to the growing demand from the society (Costanza et al. 1997). In this context, consideration should be given to integrating ecosystem services into the decision-making process (Fisher et al. 2009, Kumar 2010, Filyushkina et al. 2016, Phan et al. 2017). There are pressures to provide timely information on the different aspects of their operations beyond those reflected in traditional financial and cost accounting methods (Burritt 2005, Schaltegger and Burritt 2010, Phan et al. 2017). One way to do this is to use environmental management accounting (EMA), which is a voluntary approach focused on economic and environmental benefits (Jasch 2003, Burritt 2004, Burritt and Saka 2006, Gale 2006). The concept of EMA was developed during the 1990s (Phan et al. 2017) as an emphasis on sustainable development accounting. Critics of this theory state 
that organizations use environmental accounting only if they want to improve their financial performance or have the ambition to increase the sustainability of their business (LarrinagaGonzalez and Bebbington 2001, Springett 2003). However, the valuation of ecosystem services (Burritt 2004, Ninan and Inoue 2013, Sarkki and Karjalainen 2015) and their charging still remain a problem. Nevertheless, there are already some case studies on charging the forest ecosystem services (Jim and Chen 2009, Felardo and Lippitt 2016, Górriz-Mifsud et al. 2016).

Forestry has a long history of the environmental aspect (Smith and Heath 2004, Gustafsson et al. 2012). This is due to both a long and regular cycle of management (Elbakidze et al. 2013), and a number of environmental ecosystem services that are predominantly in the form of positive externalities in forestry (Myšáková et al. 2016). Unlike the market ecosystem services, most of non-market ecosystem services are often neglected and are normally not included in the environmental management accounting because they do not generate any sales (Jasch 2003).

As far as the non-market ecosystem services are concerned, from a private-ownership aspect, the wake theory is advocated in forestry (Glück 1982), i.e. that these ecosystem services are created in parallel with the wood-producing ecosystem services and therefore need not be supported. On the other hand, it is known that the demand for ecosystem services outweighs the supply (Robert and Stenger 2013).

Research in support of forest ecosystem services is primarily oriented on the public sector because if the forest owner is a state, a municipality, or another public entity interested in supporting these functions, one can refer to managerial accounting including positive externalities too (Papaspyropoulos et al. 2012). In such a case, the environmental management accounting may be an important tool to support all forest ecosystem services. In the case of private forest owners or private forest enterprises, it represents a voluntary tool or a data source for environmental reporting or for sustainable development reporting (Papaspyropoulos et al. 2012).

However, this may also be an area for changing the forestry policy towards charging the non-reproductive forest ecosystem services (Bartczak and Metelska-Szaniawska 2015, Roesch-McNally and Rabotyagov 2016), because the financial accounting system only reflects internalized positive and negative externalities which are subject to market or government regulation (Jasch 2003) according to the national and international accounting standards and frameworks (USGAAP, IAS/IFRS). These are issues of paying for ecosystem services. According to Knoot et al. (2015), paying for ecosystem services offers a potential financial benefit to landowners in exchange for active forest management. Given their non-timber focus, such payments might be particularly attractive to those landowners who do not participate in typical forestry programs (Knoot et al. 2015).

The aforementioned forestry research has not been completed yet, not only because the methods for valuating all non-market ecosystem services are still developing, but also because they have to be incorporated into the management accounting and used in the financial analyzes. It is important to discuss a solution, which comprehends all of the forestry ecosystem services and incorporate them in a system of environmental management accounting, so that forest-based ecosystem services can be included and managers have correct data for their decision-making.

The aim of the paper is to propose a methodological approach for how to include the nonmarket forest ecosystem services into the environmental management accounting so that the data could be used in the economic analyzes. The partial aim is to apply the proposed method to a selected practical example in forestry. 


\section{MATERIAL AND METHODS}

In order to solve the objectives of the paper, a research was conducted, focusing on the application of environmental management accounting in forestry. So far, this issue has not been addressed in the scientific literature, as it cannot be easily applied in forestry in comparison to industrial enterprises. The presented methodology is based on research that addressed the use of environmental management accounting in view of the long production time in forestry and a number of ecosystem services that are not charged. The subject of the research was not the methodology of valuation of these services.

First, it is necessary to answer the question of whether environmental management accounting is the most appropriate basis for decision making in forestry. Forestry is closely linked to environment protection. It is an industry that uses the forest as a means of production, outputs from forestry are used by the whole society and their importance is growing. Therefore, it is advisable to focus on environmental management accounting tailored to monitor the environmental aspects of production.

Environmental management accounting is closely related to environmental management systems and tools for which many governments provide land managers with the targeted support. In using the environmental management accounting, it is assumed that all linkages between forestry and the environment will be considered. These are not only inputs and outputs, including waste and negative externalities, but also negative effects reflecting in higher costs, both of compensation and income (Rikhardsson et al. 2005). At the same time, the general benefits should be met, i.e. increased efficiency of materials and energy use, mitigation of the impact of corporate activities, products and services on the environment, reduced environmental risks and improved business performance (Jasch 2003).

\section{Forest ecosystem services}

It is clear that there are many of them in the context of forest and forestry (Filyushkina et al. 2016). The major focus is on timber that is linked most closely to forest ecosystems and forest-related communities and industries, but it extends to fuel and pulpwood as well. According to CICES (Common International Classification of Ecosystem Services) classification, ecosystem services are divided as outlined in Tab. 1. For the final ecosystem services, CICES describes them using a five-level hierarchical structure: section (e.g. provisioning), division (e.g. nutrition), group (e.g. terrestrial plants and animals for food), class (e.g. crops), and class type (e.g. wheat).

Another important issue in the classification of services is the distinction between private and public ecosystem services. Public services are characterized by non-rivalry and non-excludability. Non-rivalry implies that the use/consumption of a service by one individual does not reduce the availability thereof for another individual, for example, climate regulation. This view is based on the definition of externalities, i.e. costs that do not pass through the market and are not reflected in corporate financial indicators (Mäler 1991). 
Tab. 1: Systematization of forest production and non-production functions in the concept of forest ecosystem services.

\begin{tabular}{|c|c|c|}
\hline \multicolumn{3}{|c|}{ Production (goods and services) } \\
\hline \multirow{2}{*}{ Production functions } & \multicolumn{2}{|c|}{ Non-production functions, forest ecosystem services } \\
\hline & Ecological functions & Social functions \\
\hline Services & Basic services & Cultural services \\
\hline $\begin{array}{l}\text { Source of food, drinking water, } \\
\text { building material, energy, genetic } \\
\text { material }\end{array}$ & $\begin{array}{l}\text { Soil, oxygen, carbon bonding, } \\
\text { climate regulation, nutrient cycle, } \\
\text { pollination }\end{array}$ & \multirow{3}{*}{$\begin{array}{l}\text { Recreation, aesthetic and spiritual } \\
\text { experiences, spirituality, social } \\
\text { functions, knowledge and } \\
\text { learning, artistic inspiration, } \\
\text { health-hygienic functions }\end{array}$} \\
\hline Goods & Regulatory services & \\
\hline $\begin{array}{l}\text { Wood, game, non-timber } \\
\text { functions }\end{array}$ & $\begin{array}{l}\text { Water treatment, soil erosion } \\
\text { prevention, air purification, waste } \\
\text { assimilation, conservation of } \\
\text { biological conditions }\end{array}$ & \\
\hline
\end{tabular}

Source: Ninan and Inoue (2013), Wallace (2007), own elaboration.

Forest management acts as a regulator or producer of ecosystem services, and is based on forest functions as a source of these services. Although there is a general theory by Glück (1982) that forest management is a wood-producing ecosystem service and other ecosystem services are created in parallel, in view of the development of forestry policy and the demand from the society, it is clear that this wood-producing ecosystem service may not be the key goal of forest management (Hájek and Lípa 2015). By incurring the costs of other than wood-producing ecosystem services in forestry, these environmental management costs can be assigned to different domains according to the environmental management accounting structure (Hájek 2013), such as carbon sequestration in air and climate protection.

For the choice of ecosystem services, we shall further deal with, a regional aspect that is important because ecosystem services, i.e. forest services used and supported, depend on habits and laws in individual countries or regions (Šišák 2013). At the same time, however, some ecosystem services are clearly of global character such as carbon sequestration.

The paper deals with the following ecosystem services: soil-protective, hydrological, carbon sequestration, health-hygienic, cultural-educational. This selection of ecosystem services needs to be done in specific cases in order to choose the most important ecosystem services provided or preferred in the given region at the time. In this particular case, the choice corresponds to the conditions of the Czech Republic.

\section{Accounting in physical units}

The commonly known accounting scheme in physical units can be supplemented by ecosystem services (see Tab. 3). However, this is not just about the positive externalities, as mentioned in Papaspyropoulos et al. (2012), but also about ecosystem services provided by forestry, which are linked to set objectives (priorities). This is why the main product/output in urban forests can be health-hygienic and cultural-educational ecosystem services (Hájek et al. 2012, Hájek and Lípa 2015).

It is also essential to distinguish between the low use of ecosystem services or the higher use where the non-rival becomes the rival (Merlo et al. 2000, Fisher et al. 2009) and whether it is the main product or side product according to EMA's classification. Next here comes a question whether certain ecosystem services should be considered as positive externalities.

In the EMA methodology guidance, it is further stated that the terms of Inputs and Outputs do not include capital items such as land. In forestry, however, land and particularly soil quality is a key input from which the quantity and quality of outputs are derived. On the other hand, 
the quality of forest soil is a constant quantity. Therefore, it is important to mention this in the section of accounting in physical units, but it will not be included in the input / output analysis itself (Tab. 3).

Tab. 3: Inputs and Outputs.

\begin{tabular}{|c|c|}
\hline Input in $\mathrm{kg}, \mathrm{GJ}, 1$ / period & Output in $\mathrm{kg}$ (or other / period) \\
\hline Raw materials - tree seeds & $\begin{array}{l}\text { Main product - wood-producing ecosystem } \\
\text { function - raw wood, chips, timber, wood products } \\
\text { and/or other ecosystem services if prioritized in } \\
\text { forestry (e.g. health-hygienic, cultural-educational } \\
\text { in urban forests) }\end{array}$ \\
\hline $\begin{array}{l}\text { Excipients - chemicals used in forest nurseries } \\
\text { and in protecting young cultures against biotic } \\
\text { agents }\end{array}$ & $\begin{array}{l}\text { By-product - other ecosystem services if actively } \\
\text { supported by forestry but not the main purpose of } \\
\text { forest management }\end{array}$ \\
\hline $\begin{array}{l}\text { Operating substances - substances used to ensure } \\
\text { the operation of administrative and production } \\
\text { activities }\end{array}$ & $\begin{array}{l}\text { Positive externalities - ecosystem services that arise } \\
\text { spontaneously and are not associated with costs or } \\
\text { sales }\end{array}$ \\
\hline Energy & Waste \\
\hline $\begin{array}{l}\text { Fuel (forestry machines, harvesters, forwarders, } \\
\text { timber transport units, timber loaders, passenger } \\
\text { transport) }\end{array}$ & Common waste from administrative buildings \\
\hline $\begin{array}{l}\text { Electricity (administrative work, forest nurseries, } \\
\text { sawmill) }\end{array}$ & Seedlings that failed \\
\hline Biomass (logging residues, sawdust, bark) & Small wood (logging residues) \\
\hline \multirow[t]{3}{*}{$\begin{array}{l}\text { Water (municipal water, groundwater, surface } \\
\text { water) }\end{array}$} & $\begin{array}{l}\text { Waste water - in administrative buildings (amount } \\
\text { of waste water, heavy metals, COD, BOD5) }\end{array}$ \\
\hline & $\begin{array}{l}\text { Emissions to air - from cultivation and logging } \\
\text { machinery and from vehicles }\left(\mathrm{CO}_{2}, \mathrm{CO}, \mathrm{NO}_{\mathrm{x}} \text {, }\right. \\
\mathrm{SO}_{2} \text {, dust, } \mathrm{NH}_{4} \text {, volatile org. substances) }\end{array}$ \\
\hline & $\begin{array}{l}\text { Others - e.g. negative externalities - impact of } \\
\text { logging machines on soil and vegetation, noise }\end{array}$ \\
\hline
\end{tabular}

Source: own

If we neglect the land as a specific capital, tree seeds and chemicals for the protection of young trees against biotic factors are the inputs. Fuel is also important because forestry operates on large sites. Specific is the view of water, which is mainly used for irrigation in forest nurseries (except in administrative buildings) throughout the forest growing period; however, water is taken from the air (precipitation, humidity) similarly to agriculture, unless irrigation is used. Essential for the ecosystem services are outputs. These are divided into:

i) The main product resulting from the objective or from the management priorities, as a rule the wood-production ecosystem service;

ii) By-products are other ecosystem services that are supported by forestry but are not of a priority character;

iii) Positive externalities are ecosystem functions that are not target-supported and emerge spontaneously with the wood-producing or other ecosystem services.

\section{Monetary valuation}

Forest management is similar to public enterprises, because public enterprises are established not only to generate a surplus, but also or mainly to meet social requirements. As a rule, public 
enterprises produce worse operating results as compared with the private ones because they often set out to provide also services (positive externalities) for which they do not get paid directly or have to cover the costs of ecosystem services from their own, i.e. public, resources. The outcome is that public enterprises tend to have higher environmental costs, but revenues from the timberproduction ecosystem services are no higher, and may be lower, compared with the private enterprises (Hájek and Lípa 2015). It can be stated that the public enterprises internalize the externalities (positive externalities) to a higher extent than the private ones, but at the expense of their profits (Zhang 2005). In spite of the fact that the environmental accounting methodology is well established and applied in different sectors, it is appropriate to consider the specific criteria relevant to forestry. When monitoring, in the context of environmental management accounting, the forest ecosystem services can be broken down into individual pillars, which are economic services, environmental services and social services (Ševčík et al. 2014). The economic part includes forest ecosystem services such as timber-production, game management, or other services passing through the market and these data are reported routinely. Other ecosystem services are non-market ecosystem services and it is necessary to use an appropriate method for their valuation (Vincent and Binkley 1993, Šišák 2013) if we want to include them in decision-making tools. In the context of environmental management accounting, corresponding costs and sales (subsidies) in the environmental areas are monitored (Jasch and Lavicka 2006). In connection with the forest ecosystem services, following data can be monitored.

Costs and sales that are allocated to ecosystem services are identified on the basis of annual income statements (Krieger 2001). It is important to assign costs to individual ecosystem services. These costs are related to the targeted support of these services (intensification) (see accounting in physical units). They are included in the main products or by-products. For private forest enterprises, these costs are generally zero or negligible because the ecosystem functions are supported in parallel with the production ecosystem functions in the sense of wake theory (Glück 1982). Another approach would be to budget the total costs of all ecosystem services. In that case, the ratio between them would have to be established, probably using an expert method, or a proportion corresponding to the priorities of individual ecosystem services. Furthermore, this ratio should correspond to the forest category in the sense of what is the main output, whether the wood-producing ecosystem service or another service, e.g. recreational (in the case of urban forests). This approach was not used for a large proportion of subjective assessments. Where no costs or revenues can be assigned, externalities in question are positive. For CBA (Cost Benefit Analysis) purposes, all ecosystem services are valued in the last row. This value is not reflected in the accounting and is calculated based on the methodology chosen.

There are a number of methodologies for valuing forest ecosystem services, which are based on different approaches. For the purposes of this article, methodological approaches of the Czech University of Life Sciences Prague were used for the valuation of forest-based ecosystem services dwelling on the society demand for forest functions. This methodology was selected for practical verification of the proposed methodological approach. The ambition of this paper is not to compare individual ecosystem valuation methodologies, but rather to suggest ways for how to include major non-wood ecosystem services in the decision-making process and how to use this information in the financial analysis. The system for evaluating the socio-economic importance of forest services for the society was derived for the conditions of the Czech Republic and the methodology was approved by the Ministry of Agriculture (Šišák 2013).

The socio-economic value of the forest services related to soil erosion control in stony and steep localities (intro-skeleton erosion) was derived on the basis of extra costs required for reforestation of the land including importing new soil and stabilizing the soil in the given plots. The socio-economic value of protection against eroded soil deposits in water streams and reservoirs was calculated using the costs of removing the soil deposits from watercourses and reservoirs. 
The socio-economic valuation of the hydrological forest services was based on the "costs-of-prevention approach". The costs were calculated for technical measurements such as retention reservoirs, other constructions and equipment, which could be substituted in place of the hydrological forest services, which reduce and attenuate maximum runoff to watercourses, enhancing low-flows in watercourses and reducing the concentration of nitrogen oxides in watercourses and reservoirs.

According to (Myšáková et al. 2016) forests reduce greenhouse gas emissions and the level of pollution, increase security of supplies, and strengthen economic growth, competitiveness and regional development. The air protection forest services, especially $\mathrm{CO}_{2}$ sequestration, have similar socio-economic characteristics as the hydrological and soil protection forest services. They influence market relations as the trade with $\mathrm{CO}_{2}$ permits development of market.

The mean socio-economic value of non-market forest production services for the society was experimentally derived from the shadow market values (current prices) of main non-wood forest products collected by forest visitors.

An expert method was based on the comparison of the mean general socio-economic importance of health-hygienic forest services with the mean general socio-economic importance of timber production forest services. Thirty-nine Czech experts in forest services from all important research institutions in the Czech Republic were questioned about their preferences regarding the relative socio-economic importance of the respective services and timber production service. The resulting expert ratio was 0.33 (Šišák 2013). The mean general value of health-hygienic forest services was derived from the timber production forest service value by this rate.

For the expression of the socio-economic value of cultural-educational environmental forest services, the expert approach was employed using a comparative method, i.e. comparing their general mean socio-economic importance to the general mean socio-economic importance of timber production service. It was the same procedure as used in the case of health-hygienic forest services. The resulting ratio was 0.28 (Šišák 2013) for the Czech Republic and it was used for expressing the mean general socio-economic value of the cultural-educational forest services in the Czech Republic. Local differentiation was based on landscape zoning that represents different qualities and grades of nature conservation.

\section{Profitability}

The assessment is based on a table of environmental management accounting data. It is necessary to consider that costs and revenues related to the non-production ecosystem services are normally included in the financial statements, but the value of these services is usually not reflected there (Hajek 2013). If the value of these services is used in the analyses on the part of benefits (revenues), then it is necessary to have a corresponding reduction of this value in the revenues reported to avoid duplicate inclusion of some items.

The purpose of profitability indicators is to evaluate the success of achieving the organization's goals, considering the resources invested. Profitability is assessed in relation to costs and expenses and is analyzed against assets to determine how effective the company is in the deployment of assets for generating sales and/or profit.

In the financial analysis, as an example, profitability $\left(\mathrm{P}_{\mathrm{C}}\right)$ is shown and calculated using conventional accounting (Kocmanová et al. 2013, Kojola et al. 2012):

$$
P_{c}=\frac{\text { revenues }}{\text { costs }}
$$

And corrected profitability $\left(\mathrm{P}_{\mathrm{CC}}\right)$ is calculated using environmental management accounting which includes the value of non-production ecosystem services $\left(\mathrm{V}_{\mathrm{ES}}\right)$ reduced by the revenues 
attributable to these services $\left(\mathrm{R}_{\mathrm{ES}}\right)$ (see monetary expression of EMA). Costs also include costs associated with non-productive ecosystem services $\left(\mathrm{C}_{\mathrm{ES}}\right)$ :

$$
P_{c C}=\frac{\text { revenues }+V_{E S}-R_{E S}}{\cos t s+C_{E S}}
$$

\section{Reporting}

Thanks to the process approach, environmental management accounting provides primarily the information on cost items related to environmental issues, but also a set of material and other system flows. In the form of environmental reporting, EMA-related reports are provided to relevant bodies. Environmental reporting is further specified in ISO 14063 - Environmental Management - Environmental Communication and EMAS (Eco-Management and Audit Scheme). Environmental reporting has evolved over time into sustainability reporting (Hahn and Kühnen 2013). In the growing scientific debate on sustainable forest management, the development of appropriate assessment tools plays a key role (Goio et al. 2008). The process of environmental reporting enables businesses to communicate better with the stakeholders. The most famous international activity is in the area of environmental reporting, The Global Reporting Initiative (GRI), which focuses on the standardization of Sustainable Development Reports (Papaspyropoulos et al. 2012).

\section{Verification of practical use}

The data is applied in two forest enterprises. Enterprises were chosen, in which the woodproducing ecosystem function is not a primary goal and a targeted support of some other functions is expected. The first of them was the University Forest Establishment in Kostelec nad Černými Lesy (UFE) and the second one was the Forest Plant Židlochovice (FPZ).

UFE was established under Act No. 111/1998 Coll., on Czech universities, as a specialpurpose facility within the organizational structure of the Czech University of Life Sciences in Prague (CULS) in accordance with the position and program specified by the CULS Statute. Its main activity focuses on the material and human resources for learning and practical training, students' exercises, excursions, operation of practical demonstrations based within the premises of the facility and the provision of boarding and lodging services for CULS students and teachers.

The Forest Plant Židlochovice (FPZ) manages a total of 22,500 hectares of state-owned forests. The average percentage of forest land in the area covered by FPZ is only $15 \%$ due to the intensively farmed agricultural land. As regards the whole forest area, timber production is the most important output for the Forest Plant Židlochovice, but there is also the production of cultural-educational services (nature conservation forest service) and health-hygienic services (recreational service) although the benefits in conventional accounting only include timber production and hunting and game management (Lien et al. 2007).

\section{RESULTS AND DISCUSSIONS}

The results of research at the University Forest Establishment in Kostelec nad Černými Lesy (UFE) and the Forest Plant Židlochovice (FPZ) are found below. The results are based on available data available in selected forestry companies. These are data that are tracked outside the normal accounting system. It is therefore not possible to obtain these data for all businesses.

\section{University Forest Establishment in Kostelec nad Černými Lesy}

Item costs and prevention are based on actual (additional) costs of support to the ecosystem services concerned (see Tab. 4). 
Vol. 65 (1): 2020

Tab. 4: Non-market ecosystem functions of UFE in thousands of EUR per year.

\begin{tabular}{|c|c|c|c|c|c|}
\hline \multirow{2}{*}{$\begin{array}{l}\text { Categories of } \\
\text { environmental costs } \\
\text { and revenues }\end{array}$} & \multicolumn{5}{|c|}{ Ecosystem services } \\
\hline & Soil-protective & Hydrological & $\begin{array}{c}\text { Carbon } \\
\text { sequestration }\end{array}$ & $\begin{array}{l}\text { Health- } \\
\text { hygienic }\end{array}$ & $\begin{array}{l}\text { Cultural- } \\
\text { educational }\end{array}$ \\
\hline Environmental costs & 0 & 0 & 0 & 144.5 & 31.0 \\
\hline $\begin{array}{l}\text { Environmental } \\
\text { revenues }\end{array}$ & 0 & 0 & 0 & 0 & 65.6 \\
\hline $\begin{array}{l}\text { Valuation of } \\
\text { ecosystem services }\end{array}$ & 1.0 & 432.0 & 241.6 & 691.8 & $1,673.0$ \\
\hline
\end{tabular}

Source: own

In the case of cultural and educational services, the costs in question are costs associated with the provision of teaching students. As to the health-hygienic services, the costs in question are primarily those associated with the maintenance of roads that serve recreation and forestry production. It is therefore necessary to avoid double accounting. In the statement of assets and liabilities, we can include an increase in the economic value of forest assets by the capitalized value of ecosystem services, which is 170 thousand EUR.

In the "Income Statement", all costs and revenues are reflected. However, the value of ecosystem services is not stated and amounts to 3.4 thousand EUR, which requires a corresponding reduction in revenues of 65.6 thousand EUR. After this adjustment of financial statements, we can proceed to the financial analysis itself. The selected indicator of cost profitability in this case - formula (1) will increase from 1.346 (classic profitability) to 4.093 (corrected profitability, formula 2), i.e. an increase of $304 \%$.

\section{Forest Plant Židlochovice}

In FPZ, the costs and sales related to each of ecosystem services were not measured, but the ones related to multifunctional management were measured instead (see Tab. 5). Since the revenues related to the individual specified ecosystem services were not demonstrable, the values given correspond to the loss of income related to timber-production and only one value for all ecosystem services is provided.

In the statement of assets and liabilities, we can include an increase in the economic value of forest assets by the capitalized value of ecosystem services, which represents the amount of 587 thousand EUR.

In the "Income Statement", all costs and sales are reflected; however, the value of ecosystem services is not given and it amounts to 11,709 thousand EUR, which the authors have to reduce by the corresponding revenues, i.e. by -34 thousand EUR.

Tab. 5: Non-market ecosystem functions of the Forest Plant Židlochovice in thousands of CZK per year.

\begin{tabular}{|c|c|c|c|c|c|}
\hline \multirow{2}{*}{$\begin{array}{l}\text { Categories of } \\
\text { environmental costs } \\
\text { and revenues }\end{array}$} & \multicolumn{5}{|c|}{ Ecosystem services } \\
\hline & Soil-protective & Hydrological & $\begin{array}{c}\text { Carbon } \\
\text { sequestration }\end{array}$ & $\begin{array}{l}\text { Health- } \\
\text { hygienic }\end{array}$ & $\begin{array}{c}\text { Cultural- } \\
\text { educational }\end{array}$ \\
\hline Environmental costs & \multicolumn{5}{|c|}{152.0} \\
\hline $\begin{array}{l}\text { Environmental } \\
\text { revenues }\end{array}$ & \multicolumn{5}{|c|}{-34.0} \\
\hline $\begin{array}{l}\text { Valuation of } \\
\text { ecosystem services }\end{array}$ & 12.0 & $2,381.0$ & 950.0 & $3,289.0$ & $4,727.0$ \\
\hline
\end{tabular}

Source: own 
After the adjustment of financial statements, to take account of the ecosystem services, the authors can proceed to the financial analysis itself. The selected indicator of profitability in this case increased from 1.181 to 3.492 , i.e. an increase of $195 \%$. It is an example of multifunctional economy and that is why the costs and the revenues for all ecosystem services are combined (Kovalč́k et al. 2012).

Traditional forest management and its related market opportunities often yield additional public benefits; for example, timber harvesting can improve forest health and yield financial returns that incentivize maintaining forest cover (Knoot et al. 2015). The proposed approach and practical results confirm that it is possible to integrate the forest ecosystem services into environmental management accounting (Maroto et al. 2013). The general methodology of this approach can be used in the case of monitoring the costs and benefits of environmental services (Prabhu et al. 1998). It is suggested that the use of such approaches to multifunctional forest management, or fostering non-traditional ecosystem services, should be applied and supported mainly by public forest owners (Maroto et al. 2013).

When analyzing the costs and revenues related to ecosystem services, the fundamental issue is that a substantial part of accounting for ecosystem services has been created on the basis of wake theory, which was originally based on the priority of the timber-producing ecosystem function (Dietrich 1941). Multi-functionality and the recognition of trade-offs have promoted silvicultural practices based on the continuous tree canopy coverage, uneven aged and mixed species forests which are considered to be more suitable in achieving soil conservation together with wood production (Papenfuß 2014). Other ecosystem functions like sports, leisure, ecology, landscape, habitats have been rather easily accepted because, at least some of them have followed in the "wake" of the soil conservation measures (Vincent and Binkley 1993, Bernatzki 2012). However, the most recent developments in accounting for ecosystem services show an increasing conflict amongst several emerging functions (e.g. sports versus conservation) (Merlo and Briales 2000). Another view is that forests are considered to be adequately managed for recreation if they are managed by following the principles of close-to-nature forest management (Jay and Schraml 2013).

Nowadays the importance of forests for the environment is estimated more highly than their economic value for timber production (Bernatzki 2012, Hájek and Lípa 2015). The specific share depends on all ecosystem services, which the forest in question performs. Forest services are differentiated by their diverse socio-economic essence and impact on the society, how they are used in the society and by the availability of input data.

It is important to include data obtained through using environmental management accounting in completing financial statements and when making operational and strategic decisions. Problems may occur in the annual calculation of the value of non-market ecosystem services, but it can be assumed that this value does not show significant annual variation and it is therefore possible to monitor any annual increase or decrease based on the factor that will be chosen. For example, cultural and hygienic services may vary mainly depending on the flow of visitors to the forests (Hillman and Keim 2001). Therefore, it would be appropriate to monitor the trend of the flow of visitors annually and to use the data to correct the value of this service.

Taking the ecosystem services on the balance sheet into account, we should reflect an increase in their value in the valuation of assets. Subsequently, the value of ecosystem services in the financial analysis should be considered (Roman et al. 1999). Current developments imply that the importance of non-production ecosystem services will continue to grow and hence the benefits expressed by the value of these functions will grow too (Schmithüsen 2007). 


\section{CONCLUSIONS}

For enterprises in forestry, the environmental management accounting includes forest ecosystem services. The valuation of market and non-market ecosystem services can be included in costs and revenues. Based on the information obtained by this approach, it is possible to prepare a financial analysis that also takes environmental and social benefits of ecosystem services into account.

The example of two enterprises (UFE and FPZ) clearly shows how important it is to consider the value of all forest ecosystem services. In UFE, the profitability will increase from 1.346 to 4.093 and in FPZ, it will increase from 1.181 to 3.492 .

Ecosystem and services of the forest have a higher value than the market ecosystem services and it is, therefore, important to consider their value and to make decisions based on economic analyses including the valuation of all ecosystem services of the forest. It can be expected that the importance of ecosystem services of the forest will grow in the future, particularly in the nonproductive services, based on the increasing social demand. In this context, it can be also expected that economic calculations considering all ecosystem services will become increasingly important.

\section{ACKNOWLEDGMENTS}

This paper was supported by IGA of the Czech University of Life Sciences Prague, Faculty of Forestry and Wood Sciences, Project No. B08/17 and Project No. QK1920391 financed by Ministry of Agriculture of the Czech Republic called Diversification of the Impact of the Bioeconomy on Strategic Documents of the Forestry-Wood Sector as a Basis for State Administration and the Design of Strategic Goals by 2030.

\section{REFERENCES}

1. Bartczak, A., Metelska-Szaniawska, K., 2015: Should we pay, and to whom, for biodiversity enhancement in private forests? An empirical study of attitudes towards payments for forest ecosystem services in Poland. Land Use Policy 48: 261-269.

2. Bernatzky, A., 2012: Tree ecology and preservation (Vol. 2). Elsevier, 366 pp.

3. Burritt, R.L., 2004: Environmental management accounting: roadblocks on the way to the green and pleasant land. Business Strategy and the Environment 13(1): 13-32.

4. Burritt, R.L.,2005: Challenges for environmental management accounting. In: Implementing environmental management accounting: status and challenges. Eco-efficiency in industry and science (eds. Rikhardsson, P.M., Bennett, M., Bouma, J.J., Schaltegger, S.). Pp 19-44, Vol 18. Springer, Dordrecht.

5. Burritt, R.L., Saka, C., 2006: Environmental management accounting applications and eco-efficiency: case studies from Japan. Journal of Cleaner Production 14(14): 1262-1275.

6. Costanza, R., d'Arge, R., De Groot, R., Farber, S., Grasso, M., Hannon, B., Raskin, R.G., 1997: The value of the world's ecosystem services and natural capital. Nature 387(6630): 253-260.

7. Dietrich, V., 1941: Forestry Business Administration, Vol. III. Income statement, Berlin, $266 \mathrm{pp}$.

8. Elbakidze, M., Andersson, K., Angelstam, P., Armstrong, G.W., Axelsson, R., Doyon, F., Pautov, Y., 2013: Sustained yield forestry in Sweden and Russia: how does it correspond to sustainable forest management policy. Ambio 42(2): 160-173. 
9. Felardo, J., Lippitt, C.D., 2016: Spatial forest valuation: The role of location in determining attitudes toward payment for ecosystem services policies. Forest Policy and Economics 62: 158-167.

10. Filyushkina, A., Strange, N., Löf, M., Ezebilo, E.E., Boman, M., 2016: Non-market forest ecosystem services and decision support in Nordic countries. Scandinavian journal of forest research 31(1): 99-110.

11. Fisher, B., Turner, R.K., Morling, P., 2009: Defining and classifying ecosystem services for decision making. Ecological Economics 68(3): 643-653.

12. Gale, R., 2006: Environmental management accounting as a reflexive modernization strategy in cleaner production. Journal of Cleaner Production 14(14): 1228-1236.

13. Glück, P., 1982: The misery of the wake theory. Internationaler Holzmarkt 73: 15-18.

14. Goio, I., Gios, G., Pollini, C., 2008: The development of forest accounting in the province of Trento (Italy). Journal of Forest Economics 14(3): 177-196.

15. Górriz-Mifsud, E., Varela, E., Piqué, M., Prokofieva, I., 2016: Demand and supply of ecosystem services in a Mediterranean forest: computing payment boundaries. Ecosystem Services 17: 53-63.

16. Gustafsson, L., Baker, S.C., Bauhus, J., Beese, W.J., Brodie, A., Kouki, J., Neyland, M., 2012: Retention forestry to maintain multifunctional forests: a world perspective. BioScience 62(7): 633-645.

17. Hahn, R., Kühnen, M., 2013: Determinants of sustainability reporting: a review of results, trends, theory, and opportunities in an expanding field of research. Journal of Cleaner Production 59: 5-21.

18. Hájek, M., Pulkrab, K., Hyršlová, J., 2012: Forestry externalities in the environmental management accounting system. Problems of Management in the $21^{\text {st }}$ Century, 5 pp.

19. Hájek, M., 2013: Problematika externalit při využití environmentálního manažerského účetnictví v lesním hospodářství. (The issue of externalities and the use of environmental management accounting in forestry). Zprávy lesnického výzkumu 58(3): 280-2085 (in Czech).

20. Hájek, M., Lípa, J., 2015: Evaluation of ecosystem services from urban forests in the city of Prague. Forestry Journal 61(1): 52-57.

21. Hillman, A.J., Keim, G.D., 2001: Shareholder value, stakeholder management, and social issues: What's the bottom line? Strategic Management Journal 22(2): 125-139.

22. ISO 14063, 2006: Environmental management - Environmental communication Guidelines and examples.

27. Jasch, C., 2003: The use of environmental management accounting (EMA) for identifying environmental costs. Journal of Cleaner Production: 11(6): 667-676.

28. Jasch, C., Lavicka, A., 2006: Pilot project on sustainability management accounting with the Styrian automobile cluster. Journal of Cleaner Production 14(14): 1214-1227.

29. Jay, M., Schraml, U., 2013: Managing city forests for or in spite of recreation? Perspectives of forest managers. European Journal of Forest Research 132(1): 93-105.

30. Jim, C.Y., Chen, W.Y., 2009: Ecosystem services and valuation of urban forests in China. Cities 26(4): 187-194.

31. Knoot, T.G., Rickenbach, M., Silbernagel, K., 2015: Payments for ecosystem services: Will a new hook net more active family forest owners? Journal of Forestry 113(2): 210-218.

33. Kocmanová, A., Hřebíček, J., Dočekalová, M., Hodinka, M., Hornungová, J., Chvátalová, Z., Trenz, O., 2013: Měření podnikové výkonnosti [Measuring of corporate performance]. Littera, Brno (in Czech), 252 pp. 
34. Kojola, S., Ahtikoski, A., Hökkä, H., Penttilä, T., 2012: Profitability of alternative management regimes in Scots pine stands on drained peatlands. European Journal of Forest Research 131(2): 413-426.

35. Kovalčík, M., Sarvašová, Z., Schwarz, M., Moravčík, Z., Oravec, M., Lásková, J., Tutka, J., 2012: Financial and socio-economic impacts of nature conservation on forestry in Slovakia. Journal of Forest Science 58(10): 425-435.

36. Krieger, D.J., 2001: Economic value of forest ecosystem services: a review. The Wilderness Society, Washington, $40 \mathrm{pp}$.

37. Kumar, P., 2010: The economics of ecosystems and biodiversity: ecological and economic foundations (ed. Pushpam Kumar). Earthscan. London \& Washington, 456 pp.

39. Larrinaga-Gonzalez, C., Bebbington, J., 2001: Accounting change or institutional appropriation? A case study of the implementation of environmental accounting. Critical Perspectives on Accounting 12(3): 269-292.

40. Lien, G., Størdal, Z., Baardsen, S., 2007: Technical efficiency in timber production and effects of other income sources. Small-Scale Forestry 6(1): 65-78.

41. Mäler, K.G., 1991: National accounts and environmental resources. Environmental and Resource Economics 1(1): 1-15.

42. Maroto, C., Segura, M., Ginestar, C., Uriol, J., Segura, B., 2013: Sustainable forest management in a Mediterranean region: social preferences. Forest Systems 22(3): 546-558.

43. Merlo, M., Briales, E.R., 2000: Public goods and externalities linked to Mediterranean forests: economic nature and policy. Land Use Policy 17(3): 197-208.

44. Merlo, M., Milocco, E., Panting, R., Virgilietti, P., 2000: Transformation of environmental recreational goods and services provided by forestry into recreational environmental products. Forest Policy and Economics 1(2): 127-138.

46. Myšáková, D., Jáč, I., Petrů, M., 2016: Investment opportunities for family businesses in the field of use of biogas plants. E\&M Economics and Management, Business Administration and Management 19(4): 19-32.

47. Ninan, K.N., Inoue, M., 2013: Valuing forest ecosystem services: what we know and what we don't. Ecological Economics 93: 137-149.

48. Papaspyropoulos, K.G., Blioumis, V., Christodoulou, A.S., Birtsas, P.K., Skordas, K.E., 2012: Challenges in implementing environmental management accounting tools: the case of a nonprofit forestry organization. Journal of Cleaner Production 29-30: 132-143.

49. Papenfuß, U., 2014: How (should) public authorities report on state-owned enterprises for financial sustainability and cutback management - a new quality model. Public Money and Management 34(2): 115-122.

50. Phan, T.N., Baird, K., Su, S., 2017: The use and effectiveness of environmental management accounting. Australasian Journal of Environmental Management 24(4): 355-374.

51. Prabhu, R., Colfer, C., Shepherd, G., 1998: Criteria and indicators for sustainable forest management: new findings from CIFOR's forest management unit level research (Rural Development Forestry Network Paper (ODI) No. 23a, 20 pp), Rural Development Forestry Network, UK.

52. Rikhardsson, P.M., Bennett, M., Bouma, J.J., Schaltegger, S. (Eds.), 2005: Implementing environmental management accounting: Status and challenges (Vol. 18). Springer, Science and Business Media, Pp 19-44.

53. Robert, N., Stenger, A., 2013: Can payments solve the problem of undersupply of ecosystem services? Forest Policy and Economics 35: 83-91.

54. Roesch-McNally, G.E., Rabotyagov, S.S., 2016: Paying for forest ecosystem services: voluntary versus mandatory payments. Environmental Management 57(3): 585-600. 
55. Roman, R.M., Hayibor, S., Agle, B.R., 1999: The relationship between social and financial performance: Repainting a portrait. Business and Society 38(1): 109-125.

56. Sarkki, S., Karjalainen, T.P., 2015: Ecosystem service valuation in a governance debate: Practitioners' strategic argumentation on forestry in northern Finland. Ecosystem Services 16: 13-22.

57. Schaltegger, S., Burritt, R.L., 2010: Sustainability accounting for companies: Catchphrase or decision support for business leaders? Journal of World Business 45(4): 375-384.

58. Schmithüsen, F., 2007: Multifunctional forestry practices as a land use strategy to meet increasing private and public demands in modern societies. Journal of Forest Science 53(6): 290-298.

59. Smith, J.E., Heath, L.S., 2004: Carbon stocks and projections on public forestlands in the United States. Environmental Management 33(4): 433-442.

60. Springett, D., 2003: Business conceptions of sustainable development: A perspective from critical theory. Business Strategy and the Environment 12(2): 71-86.

61. Ševčík, M., Hájek, M., Mikulková, A., 2014: Specifics in the introduction of sustainability reporting by companies in the forestry sector. Journal of Forest Science 60: 226-235.

62. Šišák, L., 2013: Differentiated valuation of forest services by their relationships to the market and its implementation in the Czech Republic. Socio-economic Analysis of Sustainable Forest Management. Czech University of Life Sciences, Faculty of Forestry and Wood Sciences, Prague, Pp 116-122.

63. Vincent, J.R., Binkley, C.S., 1993: Efficient multiple-use forestry may require land-use specialization. Land Economics 69(4): 370-376.

64. Wallace, K.J., 2007: Classification of ecosystem services: problems and solutions. Biological conservation 139(3-4): 235-246.

65. Zhang, Y., 2005: Multiple-use forestry vs. forestland-use specialization revisited. Forest Policy and Economics 7(2): 143-156.

\author{
Miroslav Hájek \\ Czech University of Life Sciences \\ Department of Forest Technologies and Construction \\ Prague \\ Czech Republic \\ Pavla Vrabcová* \\ Czech University of Life Sciences \\ Faculty of Forestry and Wood Sciences \\ Department of Wood Processing and Biomaterials \\ Kamýcká ii76, Prague 6 - Suchdol \\ i65 2i, Prague \\ Czech Republic \\ *Corresponding author: vrabcovap@fld.czu.cz
}

